\title{
Membangun Karakter Anak Melalui Teater
}

\author{
Monita Precilia $^{1)}$, Sahrul N ${ }^{2)}$, Sulaiman Juned ${ }^{3)}$ \\ ${ }^{122) 3)}$ Program Pascasarjana ISI Padangpanjang \\ Jl. Bahder Johan Guguk Malintang, Padang Panjang-Kota Padang Panjang, Sumatera Barat 27118 \\ Email: monita@gmail.com ${ }^{1)}$ sahrul@yahoo.com ${ }^{2)}$ sulaiman@yahoo.com ${ }^{3)}$
}

\begin{abstract}
Research title is"Building of Character Children Through Theater". This research use qualitative methode with descriptive analysis. The theater performance "Run to the Moon" and the "Children's Tale" is the result of observation and the director's anger toward the children in Kampung Purus (which is usually called Kampung Puruih). Children are busy with social media so there is a lack of interaction between people. The theater performance Run to the Moon and the Children's Tale is a reality that is packed into a stage event and directly involving the children as the performer. The theater performance Run to the Moon Children's Tale can be use to build children's character, because the message of tale invite children to interact with others, diligent study and good behavior and polite. This study aims to explore the character building of children with theater performance Run to the Moon and Children's Tale using the method of Sociology of Art and Psychotherapy.
\end{abstract}

Keywords : Character, Theater, and Child

\begin{abstract}
Abstrak
Penelitian berjudul "Membangun Karakter Anak Melalui Teater" ini merupakan penelitian yang bersifat kualitatif berbentuk diskriptif analisis.Pertunjukan teater Lari ke Bulan dan Dongeng Anak merupakan hasil observasi dan keresahan sutradara terhadap anak-anak di Kampung Purus (yang biasanya disebut Kampung Puruih). Anak-anak sibuk dengan media sosial sehingga kurangnya interaksi antarsesama.Pertunjukan teater Larike Bulan dan Dongeng Anak adalah sebuah kenyataan yang dikemas menjadi sebuah peristiwa panggung dengan melibatkan langsung anakanak sebagai pelakunya. Pertunjukan teater Lari ke Bulan dan Dongeng Anak dapat dijadikan sebagai media membangun karakter anak-anak, karena pesan yang disampaikan mengajak anak-anak untuk berinteraksi dengan sesama, rajin belajar serta bertingkah laku yang baik dan sopan. Penelitian ini bertujuan untuk mengupas membangun karakter anak dengan pertunjukan teater Lari ke Bulan dan Dongeng Anak menggunakan metode Sosiologi Seni dan Psikoterapi.
\end{abstract}

Kata kunci : Karakter, Teater, dan Anak 


\section{Pendahuluan}

Bagi ahli psikologi "dalaman", mimpi, ingatan secara hipnosis $^{1}$ dan asosiasi ${ }^{2}$ kata penting bagi memahami kehidupan manusia (Bujang. 1991:82). Pertunjukan teater Lari ke Bulan dan Dongeng Anak yang dimainkan oleh anak-anak Kampung Purus menjadi media membangun karakter, karena pesan-pesan disampaikan membawa nilai positif. Lingkungan mempengaruhi karakter anak, jika anak diperkenalkan dengan hal-hal positif dan cara yang baik menjadikan anak-anak memiliki karakter baik. Anak-anak Kampung Purus tumbuh di lingkungan kurang berpendidikan, sehingga kenakalan anak telah lumrah bagi masyarakat.

Perkembangan dan pertumbuhan anak merupakan hal penting dalam menunjang fisik dan mental. Pertunjukan teater Lari ke Bulan dan Dongeng Anak sutradara Syuhendri merupakan suatu bentuk kritik dan pesan kepada anak. Pertunjukan teater Lari ke Bulan dan Dongeng Anak merupakan hasil observasi dan keresahan sutradara terhadap anak-anak di Kampung Purus (yang biasanya disebut Kampung Puruih). Anak-anak sibuk dengan media sosial sehingga kurangnya interaksi antarsesama. Permainan tradisional mampu membuat interaksi langsung antar anak-anak telah tereliminasi. Berdasarkan fenomena ini Syuhendri dalam pertunjukannya mengkritik dan memberikan contohcontoh yang baik kepada anak-anak. Anak-anak seharusnya dalam perkembangan memiliki sikap dan etika yang baik, menghindari kata-kata kotor, peduli terhadap lingkungan, dan tidak saling mengintimidasi (memojokkan teman sejawat).

Pertunjukan teater Lari ke Bulan dan Dongeng Anak mencoba memvisualkan impian anak-anak tentang kebebasan bermain bersama teman-teman. Kerinduan perhatian dan kasih sayang yang sulit mereka dapatkan. Pertunjukan ini merupakan sebuah kenyataan, dikemas menjadi peristiwa panggung dengan melibatkan langsung anak-anak sebagai pelakunya.

Pertunjukan teater Lari ke Bulan dan Dongeng Anak menggunakan berbagai bahasa ungkap verbal, lagu, gerak dan musik dirangkai dengan dramatik dan harmonis. Aktor harus mampu berakting, bernyanyi dan menari. Pergantian setting dan adegan dilakukan aktor di atas panggung menjadi bagian dari adegan pertunjukan. Kehadiran Tanah Ombak serta Pertunjukan teater Lari ke Bulan dan Dongeng Anak diharapkan dapat memutus matarantai kekerasan menyadarkan pentingnya cita-cita bagi anak-anak Kampung Purus. Melalui ini mereka mengenal dan menerima audience-audience lain, menggali kemampuan diri mereka sendiri (Wawancara Syuhendri, 07 November 2017, di Padang).

Permasalahan yang diangkat dalam pertunjukan Lari ke Bulan dan Dongeng Anak adalah permasalahan

\footnotetext{
${ }^{1}$ Hipnosis adalah keadaan seperti tidur karena sugesti

2 Asosiasi merupakan pembentukan hubungan atau pertalian antara gagasan, ingatan, atau kegiatan pancaindra
}

dialami di hari ini. kenakalan anak-anak masih dekat dengan kehidupan saat ini. Rusaknya karakter serta anak-anak yang tidak sekolah bukan hanya dialami anakanak kampung Puruih saja, berbagai daerah mengalami masalah yang sama. Lari ke Bulan dan Dongeng Anak dapat dijadikan sebagai media pembelajaran pentingnya pendidikan dan cita-cita. Pesan-pesan singkat dan instruksi standar representasi bahasa tulisan disampaikan dengan cara menarik sehingga mudah diterima oleh anak-anak. Tujuan dari penelitian ini adalah Menjelaskan pertunjukan teater Lari ke Bulan dan Dongeng Anak karya/sutradara Syuhendri merubah karakter anak yang tergabung dalam komunitas Tanah Ombak di Kampung Purus Padang.

Manfaat dari penelitian yang diharapkan peneliti adalah pertama, Penelitian ini diharapkan dapat menambah wawasan peneliti dalam ilmu yang peneliti geluti saat ini, yakni pengkajian seni teater. Dua, Penelitian ini dapat menjadi tinjauan dan rujukan untuk penggiat teater dalam melihat mengapa dan bagaimana teater dapat mempengaruhi karakter dan pola pikir masyarakat. Tiga, Penelitian ini juga diharapkan dapat menjadi pendorong para penggiat teater, untuk berkarya membangun karakter yang lebih baik bagi anak bangsa dalam pertunjukan teater. Berdasarkan paparan diatas peneliti tertarik untuk meneliti pertunjukan Lari ke Bulan dan Dongeng Anak dengan judul Membangun Karakter Anak Melalui Teater.

\section{A. Metode Penenelitian}

Penelitian ini ialah penelitian kualitatif, Tesch (dalam Tjetjep Rohendi rohidi : 2011) tahun 1990 telah mengemukakan gambaran tentang cakupan kegiatan penelitian kualitatif dengan memetakan dan memilah berdasarkan atas perhatian dalam penelitiannya. Tesch mengelompokkan penelitian kualitaif ke dalam empat jenis perhatian utamanya, yaitu: (1) karakteristik bahasa, (2) pencarian keteraturan, (3) pemahaman makna teks atau tindakan, dan (4) refleksi.

Penelitian ini menggunakan penelitian kualitatif bercorak reflektif yang terbagi ke dalam tiga bentuk yaitu (1) pendidikan seni, (2) fenomenologi refleksi, dan (3) penelitian heuristik. Penelitian seni, dilakukan melalui keterlibatan didalam lapangan atau situasi kehidupan nyata secara mendalam atau yang memerlukan waktu yang panjang. Peneliti seni harus mampu merasakan denyut dan getar-getar seni yang dikajinya. Tidak sekedar mengamatinya dengan cara melihat dan mendangar saja. Menjadi penting peneliti terlibat penuh dalam situasi kehidupan seni, yaitu situasi situasi yang berlangsung secara normal, hal-hal yang biasa dilakukan, suasana yang mencerminkan kehidupan sehari-hari individu-induvidu, kelompok, masyarakat, dan organisasi.

Peneliti seni berperan untuk memperoleh suatu tinjauan yang utuh dan mendalam tentang konteks yang sedang dikaji. Tinjauan yang dilakukannya senantiasa harus dirancang dan disusun secara "holistik" (bersistem, menyeluruh, dan terpadu); logis, terstrukutur dengan 
aturan-aturan yang tersurat dan tersirat. Penelitian seni bukanlah penelitian yang mengumbar suasana hati peneliti secara bebas, melainkan tetap harus terkendali secara rasional.

Tugas utama peneliti seni dalam penelitian kualitatif adalah menjelaskan secara teliti cara-cara orang yang berada didalam latar tertentu,karya-karya atau hasil dari tindakannya, sehingga dapat memahami, memperkirakan, mengambil langkah-langkah yang diperlukan. Dengan kata lain, peneliti harus mengelola situasi mereka sendiri dari hari ke hari. Penelitian seni berusaha mendapatkan data tentang seni dan persepsi dari para pelaku setempat "dengan pandangan dari dalam" melalui sebuah proses yang mendalam, pemahaman empatik, dan mengkaitkannya atau membatasi prakonsepsi mengenai topik dengan cara pembahasan seksama.

Penafsiran-penafsiran yang mungkin muncul tentang bahan tersebut, dan beberapa diantaranya mungkin akan lebih menegaskan penalaran teoritik atau dasar-dasar konsisten internalnya. Peneliti akan dihadapkan kepada instrumen peneliti yang kurang baku mungkin secara relatif digunakan dalam penelitian yang dilaksanakan. Namun, tetap tergantung kepada peneliti dilapangan karena pada dasarnya peneliti itu sendiri merupakan"alat pengukur" utama (human instrument) dalam kajian.

Analisis penelitian seni, memang berfokus pada cipta seni tetapi penguraiannya menggunakan kata-kata. Katakata tentang kandungan intraestetik dan ekstraestetik. Kata- kata tersebut dapat diorganisasi agar memunkinkan peneliti mempertentangkan, membandingkan, menganalisis, dan merusmuskan polapola dalam upaya memahami keseluruhannya.

Tujuan yang terutama dari penelitian seni adalah pemahaman makna (meaning) yang secara tersirat menunjukkan wujudnya kemajuan penafsiran dan bersifat tidak mutlak. Hasil temuan yang diperoleh dikemukakan dalam pelaporan yang komprehensif, holistik, dan bersifat ekspansif. Pelaporan pelaksanaan secara selektif dan penekanan-penekanan kepada hal-hal yang khas, dengan ungkapan yang artistik.

Penelitian seni lazimnya dilakukan dengan dua strategi dasar; pertama, diawali dengan memandang karya seni secara fisik. Kedua, melalui penjelajahan konteks latar (ruang dan waktu) ekspresi seni itu terkait. pertama, berkaitan dengan menifestasi fisik dalam bentuk, corak, struktur, unsur-unsur, asas-asas estetik, media serta teknik penciptaan karya, konsep atau ideaidea penciptaan karya. Semuanya laim disebut dengan "faktor intraestetik".

Kedua, berkaitan dengan faktor-faktor determinan atau signifikan secara terpadu menjadi pendukung hadirnya karya seni yang berkenaan. Strategi yang kedua mencakup aspek-aspek psikologis, sosial, budaya, lingkungan alam fisik-sertaperubaha-perubahannya, dan kebutuhan-kebutuhan lainnya dalam mewadahi perwujudan seni; latar belakang atau konteks dimana karya seni itu terkait yang laimnya disebut "faktor ekstraestetik.
Fokus dalam penelitian seni adalah karya seni atau ekspresi seni, pelaku seni, tindakan atau perilaku seni, peristiwa, latar peristiwa yang mengcakupi latar sosiobudaya serta lingkunga alam-fisik, serta berlangsungnya peristiwa. Secara sistematik sasaran penelitian bersifat terbuka dan terkait dengan sistem atau subsitem lainnya, namun jelas suatu penelitian harus berfokus pada suatu masalah tertentu. Sebuah penelitian berlaku pada ruang dan waktu. Jadi, hasil penelitian akan senantiasa dan harus terbuka untuk diuji dari waktu ke waktu, dari ruang ke ruang secara terus menerus. Fokus kajian dalam penelitian ini adalah fungsi pertunjukan Lari ke Bulan dan Dongeng Anak karya/sutradara Syuhendri.

Cara memperoleh data seni ada tiga aspek yang mendasar dari dari pengalaman-pengalaman manusia yang harus diperhatikan, yaitu; (1) karya seni yang diciptakan dan diapresiasi; pertunjukan teater berjudul Dongeng Anak karya/sutradara Syuhendri, dipentaskan di teater Taman Budaya Sumatra Barat, 28 Januari 2017. (2) apa yang diketahui oleh orang atau mereka yang terlibat dalam pertunjukan teater berjudul Dongeng Anak karya/sutradara Syuhendri. (3) apa yang dilakukan mereka dalam peristiwa dan lingkungan pada satu masa dan tempat tersebut. Memperoleh tiga aspek tersebut menunjukkan kaitan antara satu dengan yang lainnya. Dengan demikian, peneliti akan mendapatkan makna secara utuh dan menyeluruh.

Dalam memperoleh data seni dan pendidikan seni ada tiga aspek yang mendasar dari pengalamanpengalaman manusia yang harus diperhatikan, yaitu: (1) karya seni yang dicipta atau diapresiasi, (2) apa yang diketahui oleh orang atau mereka yang terlibat dalam kegiatan seni, (3) apa yang dilakukan mereka dalam peristiwa dan lingkungan pada satu masa dan tempat tertentu. Adapun data pokok dalam penelitian ini berupa video pertunjukan, sedangkan data penunjang ialah dokumentasi foto atau kliping koran yang berupa ulasan pertunjukan guna mendukung beberapa argumen peneliti.

Metode observasi adalah metode yang digunakan untuk mengamati sesuatu, seseorang, suatu lingkungan, atau situasi secara tajam terinci dan mencatatnya secara akurat dalam beberapa cara. Metode observasi dalam penelitian seni dilaksanakan untuk memperoleh data tentang karya seni dalam suatu kegiatan dan situasi yang relevan dengan masalah penelitian. Penelitian pertunjukan teater berjudul Lari ke Bulan dan Dongeng Anak karya/sutradara Syuhendri, kegiatan observasi akan mengungkapkan gambaran sistematis mengenai peristiwa, tingkah laku (kreasi dan apresiasi), pada tempat penelitian.

Melalui observasi peneliti mempelajari tingkah laku, dan hal-hal penting yang berkaitan dengan pertunjukan teater berjudul Lari ke Bulan dan Dongeng Anak karya/sutradara Syuhendri. Sebuah anggapan dapat dikemukakan bahwa tingkah laku bersifat purposive (mengandung maksud) dan ekspresi yang bersumber dari nilai-nilai, keyakinan, dan pengetahuan budaya yang lebih mendalam. Observasi dapat berlangsung dari 
catatan tentang pertunjukan teater berjudul Lari ke Bulan dan Dongeng Anak karya/sutradara Syuhendri berkaitan dengan tingkah laku yang sangat terstruktur dan terinci maupun gambaran peristiwa dan tingkah laku yang ambigu.

Teknik-teknik perekam yang tercakup dalam metode perekam, yang laim digunakan untuk membantu bahkan menjadi alat utama untuk mengobservasi dalam penelitian pertunjukan teater berjudul Lari ke Bulan dan Dongeng Anak karya/sutradara Syuhendri yaitu; (1) fotografi, (2) video, (3) perekam audio. Teknik-teknik perekam digunakan dalam penelitian ini karena dipandang lebih tepat, cepat, akurat, dan realistik berkenaan dengan fenomena yang diamati, jika dibandingkan dengan mencatatnya dengan tulisan.

Metode perekaman juga digunakan untuk mendapatkan data wawancara dari informan. Alat perekaman audio yang digunakan adalah handphone jenis samsung galaxi J. Sementara alat perekaman untuk video akan memakai handycame.

Wawancara adalah suatu teknik yang digunakan untuk memperoleh informasi tentang kejadian peneliti tidak dapat amati sendiri secara langsung. Tindakan atau peristiwa yang masa lampau ataupun karena peneliti tidak diperbolehkan hadir ditempat kejadian itu. Wawancara hanya akan berhasil jika orang atau tokoh yang diwawancarai menjelaskan tentang pertunjukan teater berjudul Lari ke Bulan dan Dongeng Anak karya/sutradara Syuhendri, dimana tokoh yang bersangkutan merupakan bagian dari pertunjukan tersebut. Pertanyaan-pertanyaan yang diajukan muncul dari upaya dialog antara peneliti dan informan, baik terlibat langsung dengan produksi pertunjukan teater Dongeng Anak atau hanya sebagai spektator atau penonton.

Imforman lain yang akan diwawancarai adalah pendukung karya diantaranya Syuhendri (sutradara), Robi W Riyodi (pemusik), Desma Rosi (Relawan Tanah Ombak), alya (aktor), Rezi Hendra Pratama (aktor), dan Areif Rahman (aktor). Informasi yang akan didapatkan dari informan adalah proses penciptaan teater Lari ke Bulan dan Dongeng Anak. Proses tersebut berkaitan dengan transfer ilmu dan praktek kepada anak-anak di perciptaan tersebut.

Dokumentasi diperlukan untuk mengambil data video yang sudah ada di sutradara (Syuhendri). Data video tersebut berupa rekaman karya teater Lari ke Bulan dan Dongeng Anak yang dipentaskan di Taman Budaya Sumatera Barat pada tanggal 28 januari 2017. Data dokumentasi lain yang berkaitan dengan pemberitaan atau kliping juga diharapkan didapat dari dokumentasidokumentasi yang ada di arsip Syuhendri dan komuntas terkait.

Data seni yang telah diporelah dari latar yang sama perlu disempurnakan, diabsahkan, dijelaskan, dan ditafsir kembali. Ketika seorang peneliti telah mengumpulkan data penelitian seni melalui suatu rancangan strategi yang disusunnya, maka langkah selanjutnya menganalisis dan menafsirkan data tersebut.
Langkah tersebut merupakan upaya atau proses untuk memperoleh keteraturan dan interpretasi bagi himpunan data yang cenderung masih ambigu.

Peneliti harus senantiasa melakukan upaya-upaya dalam menganalisis dan menafsirkan ketika berhadapan dengan seni. Analisis lebih cenderung memandang seni sebagai final (selesai). Interpretasi lebih berupa dialog terus-menerus, mencoba menelusuri perjuangan, dan pergulatan yang memunculkan karya seni, tidak tertulis tetapi dapat dibaca dan disimpulkan (secara intertekstual) dengan karya seni yang ada.

Analisis data seni adalah suatu cara bagi pencarian atau pengujian pertanyaan umum tentang keterkaitan dan yang mendasari tema; yang membangun teori dari lapangan. Interpretasi adalah proses yang mengantarai dan menyampaikan pesan yang secara eksplisit dan implisit dalam realitas.

\section{Hasil dan Pembahasan}

Budaya yang berbeda mendefinisikan kecerdasan dengan cara yang berbeda (Laura A. King, 2010; 26). Masyarakat di luar Kampung Purus pada umumnya melihat kecerdasan dalam konteks penalaran dan keterampilan berfikir, sedangkan masyarakat Kampung Purus menganggap perilaku cerdas terkait dengan keikutsertaan bertanggung jawab dalam kehidupan keluarga dan kepandaian menghasilkan uang. Para peneliti menemukan bahwa heritabilitas ${ }^{3}$ kecerdasan meningkat dari periode anak-anak hingga dewasa (dari besar 35\% saat anak-anak hingga mencapai $75 \%$ saat dewasa) (McGue, et al, 1993). Seiring bertambahnya usia, interaksi dengan lingkungan semakin kurang dibentuk oleh pengaruh orang lain pada kita seperti; orang tua anak-anak Tanah Ombak seringkali memaksa mereka untuk masuk dalam lingkungan yang tidak cocok dengan faktor keturunan mereka (berdagang dan menjadi nelayan), kehadiran Tanah Ombak mencoba memberi gambaran-gambaran kehidupan baru kepada mereka sehingga kelak menjadi seorang dewasa individuindividu ini dapat memilih kedupan yang ingin dia jalani sesuai minat kecerdasan sendiri (menjadi dokter, guru, pegawai kantoran).

Bahasa (language) adalah bentuk komunikasi baik itu lisan, tertulis maupun menggunakan bahasa Isyarat yang didasarkan pada sebuah sistem simbol. Ketika memerlukan bahasa untuk berbicara dengan orang lain, mendengarkan orang lain, membaca, dan menulis (Holf \& Shatz, 2007). Bahasa tidak hanya sekedar cara bagaimana kita bicara dengan orang lain. Tetapi juga bagaiman kita menalar dan menyelesaikan masalah. Bahasa tidak dipelajari terlepas dari keadaan sosial. Kebanyakan anak dikelilingi dari bahasa sejak usia yang sangat dini. Bahasa-bahasa yang biasa digunakan masyarakat Kampung Purus adalah bahasa yang dianggap masyarakat luar Kasar, anak-anak Kampung

${ }^{3}$ Istilah yang digunakan untuk mengukur seberapa
besar korelasi antara IQ orang tua dengan IQ anak 
Purus telah terbiasa mendengar kata-kata kotor dan caci maki dilingkungannya sehingga anak-anak menganggap kata-kata kotor menjadi hal yang lumrah dan sering diucapkannya. Anak-anak yang tumbuh dilingkungan tersebut menjadi anak-anak berkarakter keras, berbohong menjadi hal yang jamak bagi anak-anak, berfikir diskriminatif (berkelompok, membuli, status ekonomi).

Manusia adalah makhluk sosial, dari proses sosial ia memperoleh beberapa karakteristik yang mempengaruhi perilakunya. Kita dapat mengklapikasinya ke dalam tiga komponen: komponen afektif, komponen kognisi, dan komponen konatif. Komponen yang pertama, merupakan aspek emosional dari faktor sosiopsikologis; didahulukan karena erat kaitannya dengan percakapan sebelumnya. Komponen kognitif adalah aspek intelektual, berkaitan dengan apa yang diketahui manusia. Komponen konatif adalah aspek vilisional, berhubungan dengan kebiasaan dan kemauan bertindak (Jalaludin, 2002: 37). Perilaku anak-anak Kampung Purus umumnya dipengaruhi komponen afektif yang terdiri dari motif sosiogenis, sikap dan emosi.

$\mathrm{M}$ otif sosiogenis dapat juga disebut motif skunder sebagai lawan motif primer (motif biologis). Klasifikasi motif sosiogenis yaitu;

\section{W.I Thomas dan Florian Znaniecki:}

1. Keinginan memperoleh pengamalan baru.

2. Keinginan untuk mendapat respons.

3. Keinginan akan pengakuan.

4. Keinginan akan rasa aman.

David McClelland:

1. Kebutuhan berprestasi (need for achievement).

2. Kebutuhan akan kasih sayang (need for affiliation).

3. Kebutuhan berkuasa (need for power).

Abraham Maslow:

a. Kebutuhan akan rasa aman (safety needs).

b. Kebutuhan akan ketertarikan dan cinta (belongingness and love needs).

c. Kebutuhan akan penghargaan (esteem needs).

d. Kebutuhan akan pemenuhan diri (self actualization).

Sikap merupakan salah satu hal penting dari psikologi sosial, ada yang menganggap sikap hanyalah sejenis motif sosiogenis yang diperoleh melalui proses belajar (Sherif dan Sherif, 1956: 489). Sikap merupakan kecenderungan bertindak, berpersepsi, berpikir, dan merasa dalam menghadapi objek, ide, situasi atau nilai. Sikap memiliki daya pendorong atau motif (sikap tidak berdiri sendiri). Emosi menunjukkan kegoncangan organisme yang disertai oleh gejala-gejala kesadaran, keperilakuan, dan proses fisiologi (Jalaluddin, 2002: 40). Bila ada temannya yang mengejek, anak akan bereaksi secara emosional karena anak mengerti makna ejekkan tersebut (kesadaran). Misalnya; Jantung akan berdetak lebih cepat, kulit memberikan respons deng mengeluarkan keringat, dan nafas terengah-engah (proses fisiologis). Anak mungkin akan membalas ejekkan itu dengan kata-kata kasar (keperilakuan).

Manusia adalah makhluk sosial, dari proses sosial ia memperoleh beberapa karakteristik yang mempengaruhi perilakunya. Kita dapat mengklapikasinya ke dalam tiga komponen: komponen afektif, komponen kognisi, dan komponen konatif. Komponen yang pertama, merupakan aspek emosional dari faktor sosiopsikologis; didahulukan karena erat kaitannya dengan percakapan sebelumnya. Komponen kognitif adalah aspek intelektual, berkaitan dengan apa yang diketahui manusia. Komponen konatif adalah aspek vilisional, berhubungan dengan kebiasaan dan kemauan bertindak (Jalaludin, 2002: 37). Perilaku anak-anak Kampung Purus umumnya dipengaruhi komponen afektif yang terdiri dari motif sosiogenis, sikap dan emosi.

Selama pengamatan Syuhendiri anak-anak di Kampung Purus tidak memiliki perkembangan; kurang memiliki etika, tidak mementingkan pendidikan, tidak memiliki gambaran ataupun cita-cita untuk kedepannya, menganut nilai yang sama (suka berkata-kata kotor, mudah berkelahi) hal-hal tersebut memprihatinkan bagi Syuhendri. Berfikir sosial tidak hanya melibatkan persepsi dan atribusi, tetapi juga sikap. Sikap (attitudes) adalah berbagai pendapat dan keyakinan kita menganai orang lain, objek, atau gagasan sederhananya, bagaimana kita merasakan berbagai hal (Laura A. King, 2010; 184). "Orang yang dasarnya baik" dan "pendidikan merupakan kunci untuk memperbaiki masyarakat". Lebih jauh lagi kita hidup dimana orang-orang berusaha mempengaruhi sikap orang lain, seperti Syuhendri berusaha meyakinkan anak-anak Kampung Purus untuk bergabung di Tanah Ombak.

Menurut Frued, (dalam Rahma bujang, 1991: 83) sikap orang tua akan diikuti oleh personal anak, sebuah bagian super ego menjadi sikap yang sama terhadap yang lainnya, ketika tersebut telah dewasa dan menjadi orang tua dia juga akan memberikan sikap yang sama terhadap anaknya. Sama halnya dengan masyarakat Kampung Purus, lingkungan dan karakter yang tidak baik telah turun temurun. Anak-anak akan mengikuti pengaruh-pengaruh negatif dari orang tuanya dan akan menularkan kepada anaknya ketika menjadi orang tua kelak jika hal tersebut tidak dihilangkan.

Ketika berkelahi atau salah satu anak merasa dirugikan, mereka memiliki cara yang unik untuk membalasnya. Jika si A kena pukul kepalanya maka si B pun harus membalas memukul kepala, jika si A mengejek si B maka si B membalas dengan mengejak si A. Cara pembalasan tersebut tidak boleh lebih dari kerugian yang diterimanya. Hukum balas membalas masih jalan dilingkungan anak-anak Purus.

Masyarakat Kampung Purus merupakan daerah yang tertutup, tertutup dalam artian jarang sekali orang luar yang mau berkunjung ke Kampung Purus. Orang tua banyak melarang anak-anaknya bermain ke Kampung Purus karena lingkungan yang terkenal dengan hal-hal yang negatif (kasar, berkata-kata kotor, minum minuman berakohol, narkoba), lingkungan yang kumuh. Menjadi 
narapidana sudah menjadi lumrah ditengah masyarakat Kampung Purus. Sehingga anak-anak Kampung Purus tidak terbiasa menerima audiens-audiens lain.

Kebiasaan-kebiasaan buruk orang tua menular ke anak, sehingga hal-hal buruk dilakukan anak-anak menjadi biasa bagi masyarakat. Anak-anak Kampung Purus yang hidup dilingkungan yang keras sehingga memiliki daya juang yang tinggi. Kata malu, tidak bisa, mengalah, minder tidak ditanamkan anak-anak dalam dirinya sehingga apapun adalah kesempatan yang harus diraih. Sehingga jika dilempar pertanyaan anak-anak akan bersemangat untuk diberi kesempatan menjawab walaupun tidak tau dengan jawaban pertanyaan (Wawancara Syuhendri, 18 April 2018, di Padang).

Anak-anak berproses di Tanah Ombak juga tidak mendapat dukungan dan sokongan oleh keluarga, sekuatkuatnya kita membangun karakternya jika sudah berkumpul dengan keluarga hal-hal negatif akan dilakukan kembali. Sebagian besar anak-anak Tanah Ombak memiliki orang tua yang berpendidikan rendah bahkan ada yang tidak sekolah. Keluarga yang ekonomi berada dibawah garis kemiskinan, yang penting bukan pengetahuan tapi uang. Tidak ada kesadaran bagi orang tua bahwa anaknya harus lebih baik dari mereka, anaknya harus memiliki cita-cita, membangun hal-hal tersebut dirasakan Syuhendri perlu dilakukannya.

Anak-anak Tanah Ombak menempuh pendidikan formal, tapi tidak membayangkan untuk kedepannya; sampai apa jenjang pendidikannya, ingin menjadi apa ketika dewasa nanti, pesimis saja bisa membaca dan menulis di Sekolah Dasar sudah cukup (karena gratis). Jika ingin melanjutkan anak-anak lebih banyak memilih swasta karena tidak mampu bersaing di sekolah Negeri sebab pola belajar yang kaliru sehingga tidak mencapai nilai-nilai.

Berbagai aspek lingkungan dapat menyiapkan individu untuk berperilaku agresif (Laura A. King, 2010: 196). Anak-anak Kampung Purus bersikap agresif terhadap lingkungan seperti; jika anak-anak mempersepsikan bahwa tindakan orang lain tidak adil atau sengaja menyakitkan, agresif terjadi (anak-anak akan cepat membalas). Bahkan hanya kehadiran orang baru yang tidak dikenal dalam lingkungan dapat memicu pikiran permusuhan dan menghasilkan agresif anak.

Atribusi adalah berbagai pikiran kita mengenai mengapa orang-orang berperilaku seperti yang mereka lakukan dan mengenai siapa atau apa yang bertanggung jawab untuk akibat peristiwa (Laura A. King, 2010: 230). Syuhendri termotivasi untuk menemukan penyebab perilaku sebagai bagian dari upaya untu memahami tingkah laku anak-anak Tanah Ombak, sehingga Syuhendri dapat mengubah perilaku anak-anak ketika di Tanah Ombak.

Menurut Freud anak-anak sadar akan rangsangan luar, pengalaman-pengalaman (dalam memori), dengan menghindari rangsangan berlebihan (melalui penyesuaian) dan akhirnya belajar membuat penyesuaian terhadap dunia luar untuk kebaikannya sendiri (melalui aktivitas) (dalam Rahma bujang, 1991: 83). Setelah bergabung di Tanah Ombak anak-anak mendapat pemahaman baru (yang postif) sehingga anak-anak memahami tindakan-tindakan yang tidak baik. Pemahaman dan pengalaman anak-anak belajar membangun karakter baru bagi anak-anak. Sehingga halhal negatif yang biasa dilakukan mulai ditinggalkan anak-anak. Tanah Ombak dijadikan wadah anak-anak untuk belajar. Perkataan belajar mempunyai tiga arti; menemukan, mengingat, dan menjadi efesien.

Anak-anak belajar memecahkan masalah yang dihadapi dilingkungan maupun keluarga. Proses pertunjukan teater Lari Ke Bulan Dan Dongeng Anak karya/sutradara Syuhendri membuat anak-anak belajar mengingat cara-cara berkomunikasi dengan baik dan menghargai orang lain dalam kehidupannya. Karakter baik ditanamkan di tanah ombak agar efesien menjadi pemecahan terhadap suatu problem atau membentuk kebiasaan. Proses belajar pada anak-anak Kampung Purus erat sekali hubungannya dengan proses berfikir. Berpikir adalah tingkah laku yang menggunakan ide, yaitu proses simbolis.

Pertunjukan teater Lari Ke Bulan Dan Dongeng Anak karya/sutradara Syuhendri sebagai media membangun karakter menggunakan pendekatan Sigmund Freud yang bersifat evolusi, berkembang dan bersejarah. Reaksi tidak sadar anak-anak terhadap lingkungan menjadi faktor pembentuk karakter anak. Anak-anak melihat bahwa perbuatan yang dilarang dalam proses latihan teater Lari Ke Bulan dan Dongeng Anak akan membawa kepada hukuman (merasa kehilangan kepercayaan). Aturan itu menjadi imitasi dan sosioemosi untuk membentuk karakter anak-anak selanjutnya.

Freud (dalam Rahma Bujang. 1991 : 82) tahun 1922, membagi teorinya; ego, super ego, dan id. Dongeng Anak adalah proses ego untuk menghubungkan id kepada realita, maka didalam pertunjukan terdapat simbol yang menyamar sebagai kepuasan terpendam. Teater menjelaskan situasi-situasi yang telah terjadi, ia merupakan satu bentuk simbolisme sekunder apabila anak-anak itu mencoba untuk membentuk realitas bersamaan dengan simbolik ketidaksadarannya.

Pertunjukan teater Lari Ke Bulan dan Dongeng Anak adalah percobaan oleh ego untuk menghubungkan Id kepada realita. Menurut frued pesan dalam pertunjukan dapat kita jadikan pembelajaran tingkah laku bagi seseorang jika memiliki "tingkah laku tertekan" (Rahma Bujang, 1991: 85). Dalam pertunjukan teater Lari Ke Bulan dan Dongeng Anak penonton dan aktor dapat memetik pesan-pesan yang disampaikan untuk membangun karakter yang lebih baik. Cerita yang diangkat dari realitas kehidupan Kampung Purus, sehingga konteks pesan-pesan sangat dekat dengan masyarakat Kampung Purus. Pesan-pesan yang disampaikan secara langsung dan simbolis, namun mudah dipahami oleh penonton dan aktor.

Simbolisme ialah suatu bentuk pemikiran, pemikiran simbolik yang bersifat akrab dan dekat dengan dasar pertanyaannya secara langsung terdapat dalam keadaan tidak sadar. Ketika simbolisme dilahirkan dalam 
pertunjukan teater hal ini menjadi bentuk simbolisme sekunder; suatu percobaan untuk menjelaskan pemikiran ketidaksadaaran simbolik secara sadar. Simbolisme tidak sadar mewakili masa lalu dan masa kini. Lari Ke Bulan mewakili simbolisme masa lalu anak-anak Kampung Purus (etika dan moral) sedangkan Dongeng Anak lebih mewakili simbolisme masa kini anak-anak Kampung Purus (belajar dan membaca).

Pertama katarsis, pertunjukan Dongeng Anak aktor memerankan situasi-situasi tidak baik atau karakter tidak baik. Pertunjukan tersebut membangun nilai katarsis tersendiri bagi aktor tersebut, melampaui dan melebihi implikasi terapeutik ${ }^{4}$ yang diberikan ahli terapi. Dasar dari terapeutik pertunjukan adalah anak-anak belajar berproses sambil berfantasi, memberi kepuasan batin bersamaan dengan realitas. Ia menjadi suatu cara yang disukai untuk mengatasi permasalah realitas secara tidak langsung.

.....mengelangi permasalahan yang tidak dapat diselesaikan dalam keadaan yang lebih bebas, luas dan lebih mudah diubah-ubah (Rahma Bujang, 1991: 119).

Terapeutik menekankan katarsis dicapai dengan empat cara; pembebasan pisik dan mental seniman (pengkarya), aktor (yang menghidupkan watak tokoh), dan penonoton (yang sama-sama mengalami peristiwa tersebut); melalui individu dan kelompok. Katarsis dalam pertunjukan Lari Ke Bulan adalah potret kehidupan nyata yang diangkat ke panggung. Orang tua dan anak-anak yang saling tidak memahami, kehidupan yang penuh dengan carut marut (kata-kata kotor, saling ejek). Syuhendri mencoba hidup dalam dunia mereka dan mencari solusi untuk lebih baik (menjadi cermin) sehingga anak-anak dan orang tua menjadi sadar yang mereka lakukan adalah salah. Solusi tersebut adalah hasil dari makna dari pertunjukan yang dipetik oleh aktor.

Kedua Pengulangan, karena anak-anak mengulangi setiap adegan dalam pertunjukan yang memberikan kesan kepada mereka dalam kehidupan sebenarnya; reaksi dari kekuatan kesan terhadap pertunjukan. Satu kesan pasif yang diterima menimbulkan satu respon aktif dari pertunjukan. Pesan-pesan yang disampaikan dalam pertunjukan Dongeng Anak direspon oleh anak-anak dan penonton dengan mengulangi (melakukan).

......Spontan dan improvisasi, yang dengan sendirinya menghasilkan penyelesaian, dan yang tidak memerlukan "pelajaran" atau keperluan psikologi biasa anak-anak itu (Rahma Bujang, 1991: 99).

Beberapa unsur terapi dalam pertunjukan Lari Ke Bulan dan Dongeng Anak; Improvisasi dalam pertunjukan membantu anak-anak mengasimilasikan realitas seperti yang dikatakan Freud walaupun mengejutkan. Pertunjukan dapat dilihat sebagai sarana ekspresi dalaman anak-anak tersebut, dorongan dan motivasi yang menyatakan arti tersendiri. Sarana dalam wujud pertunjukan, bentuknya tergantung pada pengalaman masa lalu, kepintaran, sosial, dan kehebatan anak-anak menjadi dasar dalam pertunjukan.

\footnotetext{
${ }^{4}$ hal-hal yang berkaitan dengan terapi
}

Apabila tekanan naluri meningkat dan penyelesaian neurotik muncul, penentangan tanpa sadar terhadapnya akan membawa kepada penghasilan karya seni. Fungsi psikologi adalah pembebabasan emosi yang terpendam sehingga mencapai satu paras toleransi. Penolakan secara tidak sadar anak-anak terhadap lingkungannya menghasilkan karya Lari Ke Bulan dan Dongeng Anak. Konflik menghasilkan tekanan emosi. Bagi orang yang kreatif, idea yang "lepas landas" timbul dari keadaan tidak sadar dan selanjutnya diterima. Lari Ke Bulan hampir sepenuhnya ide dari sutradara sedangkan Dongeng Anak adalah ide sutradara dan anak-anak untuk menampilkan pertunjukan-pertunjukan menarik, anakanak mencoba memberi tawaran-tawaran ide kreatif untuk menyesuaikan pertunjukan agar lebih rileks saat pertunjukan. Ide kreatif menjadi pertukaran antara ketidaksadaran dengan ego, proses-proses ketidak sadaran menjadi pencetus ego.

Anak-anak juga berfikir asosiatif, proses berfikir dimana suatu ide merangsang timbulnya ide lain (Ahmad. 1999: 47). Jalan pikiran dalam proses berfikir asosiatif tidak ditentukan arahnya (ide-ide timbul secara bebas). Anak-anak bukan hanya berperan (menjadi aktor saja), tetapi mulai belajar mencoba ikut mengambil bagian sutradara (memberi tawaran-tawaran) untuk menyajikan pertunjukan yang menarik.

Menurut Ernst Kris, kemerosotan Ego (kemunduran fungsi ego) berlaku bukan hanya apabila ego itu melemah minsalnya ketika tidur, ketika akan tidur, dalam fantasi, ketika mabuk, dan gangguan jiwa. Hal-hal tersebut termasuk juga bagian-bagian proses kreatif. Idea frued tentang kecerdasan otak, yang baginya pemikiran prasadar "diyakini dapat menguraikan ketidaksadaran". Hal tersebut mengarah ke proses kreatif dan inventif yang lain (Rahma Bujang, 1991: 137). Pertunjukan Lari Ke Bulan dan Dongeng Anak dapat dikatakan berada diantara ketidaksadaran dan realita. Gambaran pertunjukan menunjukkan kebebasan nyata yang dilahirkan superego, terdapat gambaran ego karena hal tersebut merupakan hasil dari id.

Teater merupakan fonomena sosial, teater mempresentasikan suatu situasi sosial, pertemuan sosial, sehingga dapat dikatakan bahwa ia merupakan kerangka sosial tertentu yang melibatkan para aktor sebagai bagian integral (Nur Sahid, 2017: 128). Pembicaraan karya lakon secara sosiologis tidak dapat dipisahkan dengan konteks sosial budaya masayarakatnya atau pendukung lakon tersebut. Seberapapun besarnya unsur imajinatif suatu drama namun ia tetap berkaitan dengan suatu nilai sosial masyarakat (Nur Sahid, 2017: 105). Umumnya seorang seniman memanfaatkan kehidupan dan lingkungan sebagai bahan karyanya. Dalam hal ini tidak ada karya seni yang berfungsi sebagai sesuatu yang kosong. Atas dasar setiap karya drama dan sastra merupakan hasil pengaruh yang rumit dari faktor-faktor sosial dan kultural (Damono, 1979: 3).

Pertunjukan Lari ke Bulan dan Dongeng Anak mengangkat permasalahan realitas kehidupan anak-anak dan masyarakat Kampung Purus. Dapat dikatakan, yang 
dilakukan sutradara dalam karyanya sebagai bentuk usaha menanggapi realitas sekitar, berkomunikasi dengan realitas, dan menciptakan realitas itu sendiri dalam karyanya. Kondisi sosial tempat lahirnya Lari ke Bulan dan Dongeng Anak adalah kondisi sosial masyarakat Kampung Purus kapan saja, khususnya yang telah terjadi. Berdasarkan permasalahan yang diangkat hal ini terjadi di masyarakat pinggir laut (pinggir kota) terutama masyarakat ekonomi kelas menengah bawah. Melalui beberapa kalinya pertunjukan Lari ke Bulan dan Dongeng Anak di tempat-tempat yang berbeda cukup sebagai bukti akan kontekstualnya tema dan permasalahan yang digarap oleh sutradara.

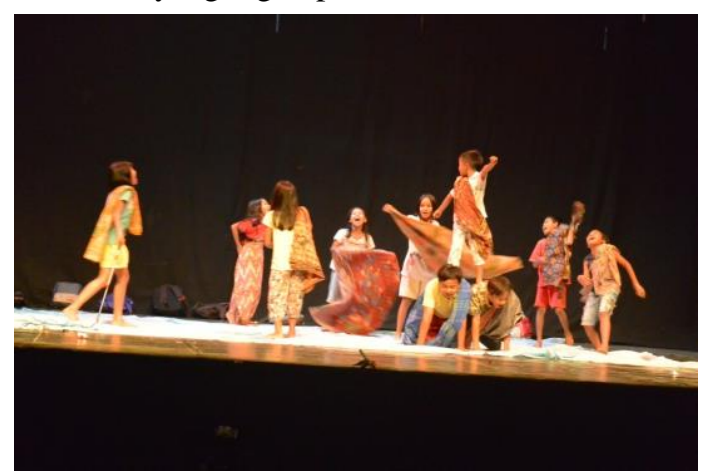

Gambar 1. Salah satu adegan anak-anak dalam teater "Lari Ke Bulan".

Kampung Purus dapat digunakan sebagai dasar pemahaman sosial dan budaya yang berpengaruh terhadap pertunjukan Lari ke Bulan dan Dongeng Anak dibatasi dengan unsur-unsur tertentu. Unsur-unsur yang dimaksud adalah kecenderungan-kecenderungan sosial yang terjadi akibat sistem ekonomi, pendidikan dan perubahan sosial di masyarakat. Jadi, pemaparan kondisi sosial budaya hanya pada pokok-pokoknya saja dan tidak sampai mendetail. Realitas sosial hanyalah bagian dari teater, sekalipun demikian aspek teaterikalitasnya tetap dan fundemental tetap sebagai suatu aspek kehidupan yang jauh lebih meresap praktik, simbol, bahkan pola normatif dan bekerja sebagai kerangka sosial.

Karya teater Lari ke Bulan dan Dongeng Anak mengandung suatu elemen atau paradoksal atau dialektika teater yang juga dinamakan sebagai dialektika ambiguitas. Pertunjukan Lari ke Bulan dan Dongeng Anak dapat dikatakan pertunjukan yang melihat dirinya sendiri (cermin). Cerita-cerita yang tercermin didalamnya membuat orang-orang memberikan perhatian, membuat penonton menangis, tertawa atau mencapai suatu keputusan revolusi yang meningkat. Karya teater Lari ke Bulan dan Dongeng Anak memberikan transendensi dan relaksasi sedemikian rupa sehingga pertunjukan tersebut merupakan integral dari anak-anak tersebut. Pertunjukan Lari ke Bulan dan Dongeng Anak merupakan suatu ekspresi dari anak-anak yang mampu membangun karakter.

\section{Kesimpulan}

Secara konseptual, pertunjukan teater Lari ke Bulan dan Dongeng Anak memvisualkan impian anak-anak tentang kebebasan bermain bersama teman-teman. Kerinduan perhatian dan kasih sayang yang sulit mereka dapatkan. Pertunjukan ini merupakan sebuah kenyataan, dikemas menjadi peristiwa panggung dengan melibatkan langsung anak-anak sebagai pelakunya. Pertunjukan teater Lari ke Bulan dan Dongeng Anak menggunakan berbagai bahasa ungkap verbal, lagu, gerak dan musik yang dirangkai dengan dramatik dan harmonis.

Pertunjukan teater Lari ke Bulan dan Dongeng Anak sutradara Syuhendri merupakan suatu bentuk kritik dan pesan kepada anak. Pertunjukan teater Lari ke Bulan dan Dongeng Anak merupakan hasil observasi dan keresahan sutradara terhadap anak-anak di Kampung Purus (yang biasanya disebut Kampung Puruih). Anak-anak sibuk dengan media sosial sehingga kurangnya interaksi antarsesama. Permainan tradisional mampu membuat interaksi langsung antar anak-anak telah tereliminasi.

Anak-anak di Kampung Purus tidak memiliki perkembangan; kurang memiliki etika, tidak mementingkan pendidikan, tidak memiliki gambaran ataupun cita-cita untuk ke depannya, menganut nilai yang sama (suka berkata-kata kotor, mudah berkelahi) hal-hal tersebut memprihatinkan bagi Syuhendri. Dapat dikatakan, yang dilakukan sutradara dalam karyanya sebagai bentuk usaha menanggapi realitas sekitar, berkomunikasi dengan realitas, dan menciptakan realitas itu sendiri dalam karyanya.

Kampung Purus dapat digunakan sebagai dasar pemahaman sosial dan budaya yang berpengaruh terhadap kecenderungan-kecenderungan sosial yang terjadi akibat sistem ekonomi, pendidikan dan perubahan sosial di masyarakat. Jadi, pemaparan kondisi sosial budaya hanya pada pokok-pokoknya saja dan tidak sampai mendetail. Realitas sosial hanyalah bagian dari teater, sekalipun demikian aspek teaterikalitasnya tetap dan fundemental tetap sebagai suatu aspek kehidupan yang jauh lebih meresap praktik, simbol, bahkan pola normatif dan bekerja sebagai kerangka sosial.

\section{Daftar Pustaka}

A. King, Laura. 2010. Psikologi Umum: sebuah pandangan apresiasif. Jakarta: Salemba Humanika.

Bujang, Rahmah. 1991. Lakon, Drama, dan Pemikiran: latar belakang Intelektual dalam pendidikan. Kuala Lumpur: Dewan Bahasa dan pustaka.

Deperteman Pendidikan Nasional. Kamus Besar Bahasa Indonesia. Jakarta: Balai Pustaka.

Fauzi, Ahmad. 1999. Psikologi Umum. Badung: CV Pustaka Setia.

Jalaluddin. 2016. Psikologi Agama: memahami perilaku dengan mengaplikasikan prinsip-prinsip psikologi. Jakarta: Pt. Raja Grafindo Perseda.

Kernodle, George. 1967. Invitation to the Theatre. New York: Harcourt, Brace \& World. Inc. 
Lickona, Thomas. 2016. Mendidik Untuk Membentuk Karakter: bagaimana sekolah dapat mengajarkan sikap hormat dan tanggung jawab. Jakarta: Bumi Aksara.

Rohidi, Tjetjep Rohendi. 2011. Metode Penelitian Seni. Semarang: Cipta Prima Nusantara Semarang.

Ritzer, George dan Dauglas J. Goodman. 2008. Teori Sosiologi; dari teori sosiologi klasik sampai perkembangan mutakhir teri sosial postmodern. Yogyakarta: Kreasi Wacana.

Rocher, Guy. 1975. Talcott Parsons and American Sosiology. New York: Barnes and Noble.

Sahid, Nur. 2017. Sosiologi Teater; teori dan penerapan. Yogyakarta: Gigih Pustaka Mandiri. 